\title{
KEANEKARAGAMAN DAN KEKERABATAN LALAT BUAH (DIPTERA: TEPHRITIDAE) DI KALIMANTAN SELATAN BERDASARKAN KARAKTER MORFOLOGI DAN MOLEKULAR (RAPD-PCR DAN SEKUENSING DNA)
}

\author{
M Indar Pramudi', Retno Dyah Puspitarini ${ }^{2}$, \& Bambang Tri Rahardjo ${ }^{2}$ \\ ${ }^{1}$ Program Studi Ilmu Tanaman Pascasarjana Fakultas Pertanian Universitas Brawijaya \\ ${ }^{2}$ Jurusan Hama dan Penyakit Tumbuhan Fakultas Pertanian Universitas Brawijaya \\ E-mail:indar_pramudi@yahoo.com
}

\begin{abstract}
Diversity and phylogeny of fruit fly (Diptera: Tephritidae) in South Kalimantan based on morphology and molecular (RAPD-PCR and DNA sequencing). Seven species of fruit fly was known by morphological identification. The fruit flies were found from trapping with methyl eugenol and fruit collecting at all study sites in South Kalimantan. The results showed that as much as 17 plants were infected by fruit fly. Dendrogram based on morphological identification analyzed by using UPGMA with MEGA 4 program consisted in a group consisting of 5 sub-groups. Bactrocera carambolae and Bactrocera papayae of morphology were still a closely related fruit fly at 0.935 . Whereas, based on RAPD result analized by UPGMA using 20 character of DNA based, showed that out of seven species consisted 2 groups, $1^{\text {st }}$ group were $B$. umbrosa, B. occipitalis and sub-group of B. latifrons. The second group consists of sub-groups B.carambolae, B. papaya, sub-group B. albistrigata and $B$. cucurbitae. The results of dendrogram from sequencing DNA fruit fly analysis comprised one of group and three subgroups. The first sub-groups were B. papayae, B. carambolae, B. occipitalis, B.latifrons. The second subgroup were $B$. cucurbitae and B. umbrosa. While B. albistrigata separate but still one group with another fruit flies. The results of DNA sequencing showed that there were a homology of the seven species of the fruit fly i.e at 83 base pair / bp (C), $101 \mathrm{bp}(\mathrm{T}), 265$ bp (G), $420 \mathrm{bp}$ (A), $432 \mathrm{bp}$ (T), $600 \mathrm{bp}$ (A). The length of the base pair for B. occipitalis, B. cucurbitae, B. albistrigata, B. carambolae, B. papayae, B. latifrons were respectively $615,898,570.969,898$ and $615 \mathrm{bp}$. The results of morphological analysis and RAPD methods showed difference in the distribution of groups and sub-groups. But based on morphologycal and DNA identification seven species of fruit flies found were all same as the genebank.
\end{abstract}

Key words: DNA sequencing, fruit fly, morphology, PCR-RAPD, South Kalimantan

\begin{abstract}
ABSTRAK
Keanekaragaman dan kekerabatan lalat buah (Diptera: Tephritidae) di Kalimantan Selatan berdasarkan karakter morfologi dan molekular (RAPD-PCR dan sekuensing DNA). Tujuh spesies lalat buah telah diketahui dari identifikasi morfologi lalat buah. Lalat buah ini didapatkan dari pemasangan perangkap dengan metil eugenol dan pengumpulan buah pada semua lokasi penelitian di Kalimantan Selatan. Diketahui 17 jenis tanaman yang diserang lalat buah dari pemeliharaan larva lalat buah hingga menjadi imago. Dendrogram hasil analisis UPGMA dari identifikasi morfologi dengan program MEGA 4 adalah satu kelompok yang terdiri atas 5 sub kelompok. Bactrocera carambolae dan Bactrocera papayae dari ciri-ciri morfologi masih berkerabat dekat sebesar 0,935, sedangkan dendrogram hasil RAPD dari 20 karakter pita DNA, menunjukkan ketujuh spesies itu terbagi ke dalam dua kelompok. Kelompok pertama terdiri atas sub kelompok B. umbrosa, B. occipitalis dan sub kelompok B. latifrons. Kelompok kedua terdiri dari atas sub kelompok B.carambolae, B. Papayae dan sub kelompok B. albistrigata, B. cucurbitae. Dendrogram dari sekuensing DNA lalat buah adalah satu kelompok dan 3 sub kelompok. Sub kelompok pertama adalah B. papayae, B. carambolae, B. occipitalis, B.latifrons. Sub kelompok kedua B. cucurbitae dan B. umbrosa. B. albistrigata terpisah tetapi masih satu kelompok yang sama dengan lalat buah lainnya. Hasil sekuensing DNA menunjukkan adanya homologi dari ketujuh spesies lalat buah tersebut yaitu pada 83 base pair/ bp (C), 101 bp (T), 265 bp (G), $420 \mathrm{bp}$ (A), 432 bp (T), 600 bp (A). Panjang base pair untuk B. occipitalis, B. cucurbitae, B. albistrigata, B. carambolae, B. papayae, $B$. latifrons berturut-turut adalah 615, 898, 570, 969, 898 dan 615 bp. Hasil analisis dari ciri morfologi dan metode RAPD menunjukkan perbedaan dalam pembagian kelompok dan sub kelompok. Tetapi dari identifikasi secara morfologi dan DNA ketujuh spesies lalat buah yang ditemukan sama dengan data dari genebank.
\end{abstract}

Kata kunci : DNA sekuensing, Kalimantan Selatan, lalat buah, morfologi, PCR-RAPD, 


\section{PENDAHULUAN}

Lalat buah sebagai hama tanaman telah diketahui sejak tahun 1920, yaitu menyerang mangga di pulau Jawa. Pada tahun 1938, lalat buah juga dilaporkan menyerang cabai, jambu, belimbing dan sawo. Pada populasi tinggi, intensitas serangannya dapat mencapai 60-100 \% (Kuswadi, 2001; Griffith University dan Ministry of Agriculture, 2008). Sebagian besar lalat buah ini bersifat polifag (Ortiz et al., 2006) dan dapat menurunkan produksi buah-buahan dan sayuran, baik secara kuantitas maupun kualitas (Sodiq, 1993; Kuswadi, 2001; Soesilohadi, 2002; Siwi et al., 2006).

Kesalahan atau kesulitan dalam identifikasi serangga secara morfologi dapat terjadi. Kalsoven (1981) menyatakan bahwa terdapat enam spesies lalat buah di Indonesia yaitu Dacus dorsalis Hendel, D. pedestris Fabricius, D. cucurbitae Coquillet, D. umbrosus Fabricius, D. caudatus Fabricius dan Adrama determinata Walker (Diptera: Tephritidae). Genus Dacus yang sebelumnya diidentifikasi terdapat di Indonesia, merupakan kekeliruan dari identifikasi dari genus Bactrocera. Dacus berasal dari Afrika bukan dari Indonesia (White \& Hancock, 2007). Dengan demikian, semua yang disebut sebagai Dacus dalam buku Kalshoven (1981) perlu diganti menjadi Bactrocera. Contoh perbedaan mofologis yang sulit dibedakan satu sama lain antara $B$. carambolae dan B. papayae karena kedekatan kekerabatannya sehingga dari ukuran tubuh dan sayap terlihat sama. Prof. Totok Himawan menyatakan bahwa sangat dekatnya hubungan kekerabatan telah menyebabkan berbaurnya kedua spesies tersebut. Keduanya merupakan spesies kembar (simpatrik) dengan perbedaan morfologi yang sangat kecil sehingga untuk dapat membedakannya perlu alat bantu (lup atau mikroskop), tidak seperti spesies lain yang bisa dibedakan langsung dengan melihat pola gambar sayap dan abdomennya. Keduanya sangat mirip namun memiliki perbedaan dalam preferensi inang, dan habitat (Hasil komunikasi pribadi).

Adanya perbedaan dari beberapa hasil identifikasi lalat buah secara morfologi atau konvensional ini menunjukkan adanya kelemahan pada metode identifikasi konvensional tersebut. Metode konvensional yang berdasarkan ciri morfologi kurang akurat akibat adanya pengaruh perubahan-perubahan lingkungan. Karakterkarakter morfologi sering tidak menggambarkan hubungan genetik akibat adanya interaksi lingkungan dan sejumlah kontrol genetik yang tidak diketahui, sehingga perlu dilakukan karakterisasi molekuler untuk mendapatkan hasil yang akurat dalam mengkarakterisasi perbedaan spesies (McPheron \& Steck, 1996; Smith et al., 2003; Siwi, 2004). Pengunaan marka molekuler RAPD banyak digunakan untuk menyusun kekerabatan beberapa individu dalam spesies maupun kekerabatan antar spesies.

Penggunaan marka molekuler RAPD juga sangat efektif pada serangga hama yang jarak migrasinya sangat jauh seperti pada belalang Locusta migratoria Linn. (Orthoptera: Acridiidae) (Heckel, 1995). Metode RAPD menggunakan oglionukleotida tunggal pendek (primer), sepanjang 10-12 basa, untuk membentuk fragmen-fragmen DNA. Metode ini mampu menghasilkan jumlah karakter yang tidak terbatas sehingga sangat membantu dalam analisis keragaman genetik (Anggereini, 2008; Fatchiyah \& Estri, 2011).

Sampai saat ini informasi tentang spesies dan kelimpahan lalat buah di Kalimantan Selatan masih sedikit serta masih adanya kesalahan / kesulitan dalam identifikasi yang dilakukan berdasarkan morfologi. Penelitian ini bertujuan untuk mengetahui keragaman jenis, kelimpahan populasi, tanaman inang lalat buah di Kalimantan Selatan. Identifikasi spesies lalat buah dalam penelitian ini dilakukan secara morfologi dan molekuler (RAPD).

\section{METODE PENELITIAN}

Penelitian ini merupakan penelitian deskriptif dengan metode survei dilakukan dalam dua tahap, yaitu pengumpulan contoh lalat buah (pemasangan perangkap dan pengumpulan buah terserang lalat buah) dan penelitian keanekaragaman berdasarkan karakter morfologi, RAPD dan sekuensing DNA. Penelitian ini dilaksanakan pada dua kabupaten dan satu kota di Kalimantan Selatan, yaitu Kabupaten Barito Kuala dan Kabupaten Banjar serta Kota Banjarbaru. Pada masingmasing lokasi itu ditetapkan tiga kecamatan contoh dan pada setiap kecamatan ditetapkan satu desa contoh, sehingga terdapat sembilan desa contoh. Kecamatan dan desa-desa itu adalah Bakumpai (Desa Lepasan), Mandastana (Desa Karang Indah), Rantau Badauh (Desa Pindahan Baru), Martapura Barat (Desa Sungai Batang), Karang Intan (Desa Sungai Alang), Astambul (Desa Kelampaian), Banjarbaru Selatan (Desa Sungai Besar), Landasan Ulin (Desa Guntung Payung), Cempaka (Desa Gunung Kupang). Penetapan jenis tanaman contoh pada setiap desa contoh tidak sama karena perbedaan jumlah dan jenis tanaman buahbuahan. Jenis tanaman contoh yang diamati pada semua desa contoh adalah 44 tanaman. Setiap jenis tanaman contoh, ditetapkan lima tanaman contoh secara acak. Pada setiap tanaman contoh dipasang sebuah perangkap, sehingga jumlah seluruh perangkap adalah1980 (9 desa 
x 44 jenis tanaman contoh $x 5$ pohon). Identifikasi lalat buah dilakukan di Laboratorium Entomologi Jurusan Hama dan Penyakit Tumbuhan Fakultas Pertanian Universitas Lambung Mangkurat, dan Laboratorium Genetika dan Biologi Molekuler Fakultas Sains dan Teknologi Universitas Islam Negeri Malang. Penelitian dilakukan pada bulan Agustus 2012 sampai Januari 2013.

Pemasangan Perangkap. Perangkap yang digunakan adalah perangkap Steiner yang telah dimodifikasi. Perangkap dengan atraktan metil eugenol yang telah disiapkan digantung pada dahan atau ranting pohon contoh dengan ketinggian lebih kurang $2 \mathrm{~m}$ dari permukaan tanah (Suputa et al., 2007). Pemasangan perangkap dilakukan selama enam minggu. Setiap minggu lalat buah yang terperangkap diambil, ditempatkan di dalam botol dan dibawa ke laboratorium untuk dihitung kelimpahannya. Penambahan atraktan pada perangkap dilakukan setiap kali setelah pengambilan lalat buah.

\section{Pengumpulan Buah Terserang Lalat Buah} dilakukan dari tanaman contoh yang sama dengan yang dipasang perangkap dan dilakukan pada hari yang sama dengan pengambilan lalat buah di perangkap. Pengambilan buah terserang dilakukan lima kali. Buah yang diambil adalah buah yang busuk dengan bintik hitam di permukaan kulit buahnya. Buah yang diambil per tanaman contoh sebanyak satu kantung plastik berukuran $1 \mathrm{~kg}$. Kemudian buah-buahan dimasukkan ke toples yang sudah disediakan di laboratorium dan diamati setiap hari sampai muncul imago. Imago yang muncul dihitung kelimpahannya (Asrida \& Susilo, 2001; Swibawa et al., 2003).

Ekstraksi DNA dan Amplifikasi DNA. Teknik ekstraksi DNA menggunakan seekor lalat buah untuk tiap tabung ependorf dengan metode Goodwin et al. (1994), Bahagiawati \& Habib (2005) dan untuk setiap spesies lalat buah diambil 20 ekor secara acak. Lalat buah ditempatkan pada tabung ependorf kemudian ditambahkan $125 \mu \mathrm{l}$ buffer ekstraksi CTAB (CTAB 2\%, $\mathrm{NaCl} 1.4 \mathrm{M}$, Tris-HCl $100 \mathrm{mM}$, EDTA $20 \mathrm{mM}$ dan Polyvinylpyrrolidone (PVP-40) 1\% dan dihaluskan dengan pistil mikro plastik. Kemudian lalat buah yang sudah dihaluskan tadi diinkubasikan pada $65^{\circ} \mathrm{C}$ selama 5 menit. Selanjutnya ditambahkan $125 \mu 1$ kloroform: isoamil alkohol (24:1) dan diinkubasikan pada suhu ruang selama 20 menit sebelum disentrifugasi pada $8000 \mathrm{rpm}$ selama 5 menit. Supernatan dipindahkan $(90 \mu \mathrm{l})$ pada tabung baru dan ditambahkan $10 \mu \mathrm{l} \mathrm{NaOAc} 3 \mathrm{M}(\mathrm{pH}$ 5.2) dan $250 \mu \mathrm{l}$ etanol absolut $\left(-20^{\circ} \mathrm{C}\right)$ kemudian diinkubasikan selama 30 menit pada suhu $-20^{\circ} \mathrm{C}$. Supernatan dibuang setelah disentrifugasi $11500 \mathrm{rpm}$ selama 15 menit. Pelet dicuci dengan $200 \mu 1$ etanol 70 $\%\left(-20^{\circ} \mathrm{C}\right)$ dan disentrifugasi pada $11500 \mathrm{rpm}$ selama 2 menit. Etanol dibuang kemudian pelet dikeringanginkan selama 10 menit selanjutnya pelet ditambah dengan 10 $\mu 1$ air steril. DNA hasil ekstraksi diamplikasi dengan teknik RAPD berdasarkan metode Gawel \& Bartlett (1993). Primer yang digunakan sebanyak lima primer berdasarkan dari penelitian sebelumnya oleh Zhang \& Zhang (2007) yang berasal dari omegabiotek (Tabel 1).

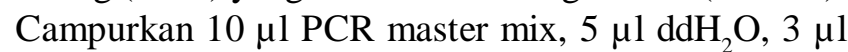
primer dengan konsentrasi $5 \mu \mathrm{M}, 2 \mu \mathrm{l}$ DNA spesies lalat buah dengan konsentrasi 20ng/ $\mu$ ke dalam PCR tube. Setting program PCR yang digunakan seperti pada Tabel 2.

DNA lalat buah hasil PCR diletakkan di atas es atau disimpan di pendingin sebelum digunakan. Sebanyak $3 \mu \mathrm{l}$ DNA lalat buah hasil PCR dicampur dengan $2 \mu \mathrm{l}$ loading dye, kemudian ditambahkan 100 bp DNA ladder dan dimasukkan ke dalam well gel agarose $1 \%$ (w/v) dalam 1X TBE. Kemudian gel dielektroforisis pada 80 Volt selama 60 menit. Hasil elektroforesis direndam dalam $1 \mathrm{mg} \mathrm{l}^{-1}$ ethidium bromide, kemudian diambil gambarnya dengan meletakkan pada lampu ultraviolet agar terlihat pita DNA yang dihasilkan.

Sekuensing DNA. Fragmen DNA hasil aplikasi selanjutnya disekuensing untuk melihat susunan DNA masing-masing spesies lalat buah dengan menggunakan mesin sekuensing ABI-:Prisma 3100-avant Genetic analyzer.

Analisis Keragaman Morfologi. Penciri utama yang digunakan ialah ada tidaknya medial postsutural vittae dan lateral postsutural vittae. Pada bagian sayap penciri utama yang digunakan adalah basal costal, costal, microtrichia, costal band, anal streak, dan pola sayap. Pada bagian abdomen, penciri utama yang digunakan ialah ada tidaknya gambaran pola $\mathrm{T}$ pada terga, menyatu atau tidaknya antar terga ke dua dan seterusnya, serta pola warna pada bagian terga. Identifikasi lalat buah dilakukan dengan kunci determinasi berdasarkan morfologi (Drew 1989; Drew \& Hancock, 1994; Siwi et al., 2006; Griffith University \& Kementerian Pertanian Indonesia, 2008) dan program Cabikey 2007. Dari perbedaan morfologi yang ada pada setiap spesies lalat buah dibuat menjadi data biner yang selanjutnya dipakai dalam analisis keragaman morfologi dengan metode pengelompokan Unweighted Pair Group Method with Arithmetic Mean (UPGMA). Data scoring 
Tabel 1. Primer yang digunakan dalam teknik RAPD (Zhang \& Zhang, 2007)

\begin{tabular}{ll}
\hline Primer & Sequence $\left(5^{\prime}-3^{\prime}\right)$ \\
\hline OPC-01 & TTCGAGCCAG \\
OPI-17 & GGTGGTGATG \\
OPL-07 & AGGCGGGAAC \\
OPL-08 & AGCAGGTGGA \\
OPL-16 & AGGTTGCAGG \\
\hline
\end{tabular}

Tabel 2. Setting program PCR untuk amplifikasi DNA

\begin{tabular}{llcc}
\hline Siklus & Proses & Suhu $\left({ }^{\circ} \mathrm{C}\right)$ & Waktu (Menit) \\
\hline Siklus 1 & & 94 & 2 \\
Siklus 2 to 35 & Denaturing & 94 & 1 \\
& Annealing & 60 & 1 \\
Final extension & Extension & 72 & 1 \\
\hline
\end{tabular}

yang telah tersusun dimasukkan dalam program pengolah data Mega 4 (Tamura et al., 2007).

Analisis Keragaman Hasil RAPD. Pola pita DNA hasil elektroforesis dari PCR-RAPD digunakan untuk mempelajari keanekaragaman lalat buah. Pita-pita DNA diubah kedalam bentuk data biner dengan memberi nilai 1 jika ada pita dan 0 jika tidak ada pita (Bahagiawati \& Habib, 2005; Fatchiyah \& Estri, 2011; Smith et al., 2003; Sappanukhro et al., 2011). Selanjutnya data biner tersebut dianalisis dengan program Mega 4 (Tamura et al., 2007).

Analisis Keragaman Hasil Sekuensing. Sekuen DNA ketujuh spesies lalat buah kemudian alignmen dengan program Bioedit dan clustalw2 dari European bioinformatics institute (http://www.ebi.ac.uk/serve/ clustalw). Kemudian hasil sekuens DNA dicocokkan dengan memanfaatkan informasi sekuen DNA yang tersedia dalam genebank (http:/www/ncbi.nlm.nih.gov). Selanjutnya dianalisis keragaman genetik dengan program pengolah data Mega 4.

\section{HASIL DAN PEMBAHASAN}

Hasil pemeliharaan larva yang berasal dari buah terserang dan perangkap lalat buah yang dipasang didapatkan tujuh spesies lalat buah (Tabel 3 dan 4). Spesies tersebut yaitu B. papayae, B. carambolae, $B$. cucurbitae, B. umbrosa, B. occipitalis, B. latiforns dan B. albistrigata. Spesies tersebut didapatkan dari
18 tanaman yang menjadi inang lalat buah. Satu jenis tanaman dapat menjadi inang dari dua atau lebih spesies lalat buah. Belimbing dan mangga diserang oleh tiga spesies lalat buah sedangkan nangka diserang oleh dua spesies (Tabel 3). Spesies tersebut merupakan spesies lalat buah yang dilaporkan sudah ada di Indonesia (Ginting, 2009).

Ketujuh spesies lalat buah yang diperoleh dari perangkap di tiga kabupaten menunjukkan adanya perbedaan populasi (Tabel 5). B.carambolae merupakan spesies dengan tingkat populasi dan kelimpahan tertinggi pada ketiga kabupaten tersebut. Di kabupaten Banjarbaru, populasi B. albistrigata paling rendah yaitu 47 individu $(0,304 \%)$ sedangkan $B$. cucurbitae tidak ditemukan. Di Barito Kuala dan Banjar, B. cucurbitae rendah yaitu satu individu $(0,096 \%)$ dan dua individu $(0,021 \%)$. Populasi lalat buah tiap kecamatan dengan kategori rendah $42 \%$, menengah $10 \%$, tinggi $38 \%$, tidak ada populasi $10 \%$.

Berdasarkan teknik identifikasi morfologi yang kemudian dianalisis UPGMA dengan mengunakan program MEGA 4, didapatkan satu kelompok yang terdiri atas lima sub kelompok. Sub kelompok pertama dimulai dari B. latifrons dan B. carambolae dengan jarak 0,957 dan diakhiri dengan sub kelompok kelima $B$. occipitalis sebesar 0,847. Jarak koefisien antar tujuh spesies lalat buah ini rata-rata sebesar 0,02 (Gambar $1)$.

Hasil amplifikasi DNA total dengan teknik PCRRAPD pada tujuh spesies menunjukkan adanya polimorfisme pada ukuran pita 500 bp (Gambar 2 dan 
Tabel 3. Berbagai spesies lalat buah yang didapatkan dari hasil pemeliharaan larva sampai menjadi imago dari pengumpulan buah terserang lalat buah

\begin{tabular}{cll}
\hline No. & \multicolumn{1}{c}{ Tanaman Inang } & \multicolumn{1}{c}{ Jenis lalat buah } \\
\hline 1 & Belimbing (Averrhoa carambola Linn) (Oxalidaceae) & B. carambolae, B. papayae, B. latifrons \\
2 & Mangga (Mangifera indica Linn) (Anacardiaceae) & B. carambolae, B. occipitalis, B. umbrosa \\
3 & Nangka (Artocarpus heterophylus Lamarck) (Moraceae) & B. latifrons, B. umbrosa \\
4 & Pepaya (Carica papaya Linn) (Caricaceae) & B. carambolae, B.papayae \\
5 & Tomat (S. lycopersicum Linn)(Solanaceae) & B. carambolae, B.papayae \\
6 & Jeruk siam (Citrus nobilis Lour) (Rutaceae) & B. carambolae, B.papayae \\
7 & Jambu air (Eugenia aquea Burm F) (Myrtaceae) & B. carambolae, B. albistrigata \\
8 & Jambu biji (Psidium guajava Linn) (Myrtaceae) & B. carambolae, B. occipitalis \\
9 & Cabai besar (Capsicum annum Linn) (Solanaceae) & B. latifrons \\
10 & Cabai rawit (C. frutescens Linn) (Solanaceae) & B. latifrons \\
11 & Sukun (A. altilis Fosberg) (Moraceae) & B. latifrons \\
12 & Cempedak (A. champeden Spreng) (Moraceae) & B. umbrosa \\
13 & Kecapi (Sandoricum koetjape Merr) (Meliaceae) & B. papayae \\
14 & Tigarun (Crataeva nurvala Buch. Ham. ) (Capparaceae) & B. carambolae \\
15 & Belimbing wuluh (Averrhoa bilimbi Linn) (Oxalidaceae) & B. carambolae \\
16 & Labu (Cucurbita maxima Duchesne) (Cucurbitaceae) & B. cucurbitae \\
17 & Gambas (Luffa acutangula (Linn) Roxb) (Cucurbitaceae) & B. cucurbitae \\
18 & Timun (Cucumis sativus Linn)(Cucurbitaceae) & B. cucurbitae \\
\hline
\end{tabular}

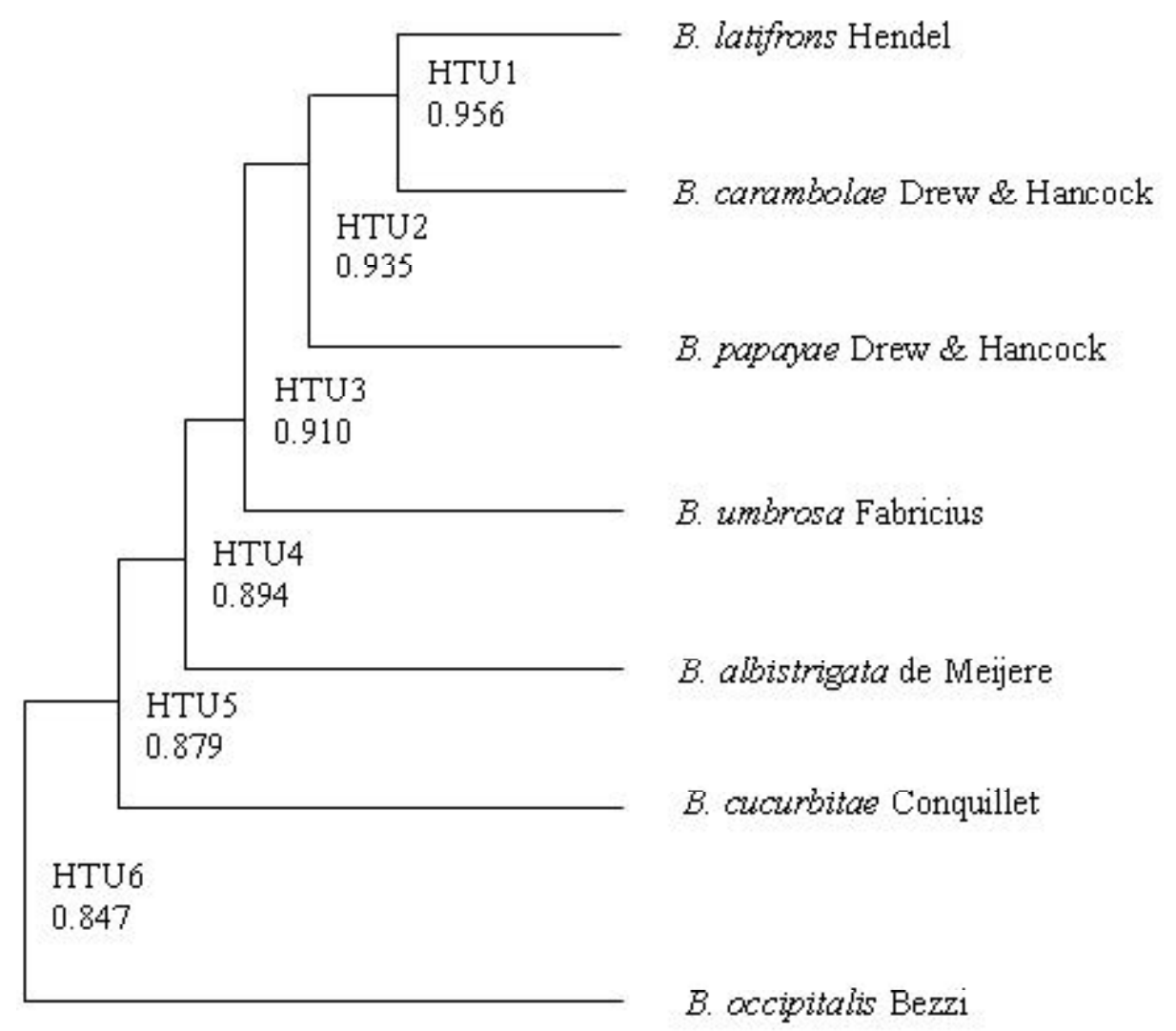

Gambar 1. Dendrogram tujuh spesies lalat buah hasil pemasangan perangkap dan pengumpulan buah berdasarkan identifikasi secara morfologi. 
Tabel 4. Hasil pemantauan lalat buah dengan perangkap (Trapping)

\begin{tabular}{|c|c|c|c|c|}
\hline \multirow{2}{*}{ Lalat buah } & \multicolumn{3}{|c|}{ Lokasi } & \multirow{2}{*}{ Vegetasi } \\
\hline & Banjarbaru & Barito Kuala & Banjar & \\
\hline B. carambolae & $\begin{array}{l}\text { LU, BS, } \\
\text { CK }\end{array}$ & MA, BA, RB & $\begin{array}{l}\mathrm{KI}, \mathrm{MB} \text {, } \\
\mathrm{AS}\end{array}$ & $\begin{array}{l}\text { Belimbing, nangka, mangga, jeruk, sawi, } \\
\text { tomat, cabe, bayam, rambutan, sawo, nanas, } \\
\text { jambu air, sirsak, petai, labu, kundur, durian, } \\
\text { pampaken, buah mentega, belimbing wuluh, } \\
\text { ketapi, srikaya, kedondong, sukun, kopi, } \\
\text { kelengkeng, melinjo, kalalayu, papaya, } \\
\text { balangkasua, cempedak, mengkudu }\end{array}$ \\
\hline B. papayae & $\begin{array}{l}\text { LU, BS, } \\
\text { CK }\end{array}$ & MA, BA, RB & $\mathrm{KI}, \mathrm{MB}$ & $\begin{array}{l}\text { Sawi, , nangka, tomat, belimbing, cabe, } \\
\text { nanas, sawo, rambutan, pisang, jambu biji, } \\
\text { jeruk, sirsak, petai, labu, kundur, durian, } \\
\text { pampaken, buah mentega, belimbing wuluh, } \\
\text { ketapi, srikaya, sukun, kelengkeng, jambu } \\
\text { air, cempedak, melinjo, kopi, kalalayu, } \\
\text { balangkasua, mengkudu, pepaya }\end{array}$ \\
\hline B. umbrossa & $\begin{array}{l}\text { LU, BS, } \\
\text { CK }\end{array}$ & MA, BA, RB & $\begin{array}{l}\mathrm{KI}, \mathrm{MB} \text {, } \\
\mathrm{AS}\end{array}$ & $\begin{array}{l}\text { Sawo, rambutan, sawi, nangka, tomat, } \\
\text { belimbing, jeruk, jambu biji, pisang, bayam, } \\
\text { mangga, buah mentega, belimbing wuluh, } \\
\text { ketapi, srikaya, sukun, labu, kelengkeng, } \\
\text { kalalayu, balangkasua, cempedak, pepaya }\end{array}$ \\
\hline B. albistrigata & $\mathrm{BS}$ & MA & - & jambu biji, jambu air \\
\hline B. latifrons & LU, BS & BA & MB & $\begin{array}{l}\text { nangka, belimbing, rambutan, sawo, sirsak, } \\
\text { petai, durian, pampaken, cempedak, labu, } \\
\text { papaya, cabai }\end{array}$ \\
\hline B. cucurbitae & - & BA & MB & Mentimun, gambas, sawo \\
\hline B. occipitalis & $\begin{array}{l}\text { LU, BS, } \\
\text { CK }\end{array}$ & BA & $\begin{array}{l}\text { KI, MB, } \\
\text { AS }\end{array}$ & $\begin{array}{l}\text { Kelengkeng, pepaya, jambu air, jambu } \\
\text { Bangkok, kecapi, belimbing, tomat, } \\
\text { Nangka,sukun, cempedak, cabe, labu }\end{array}$ \\
\hline
\end{tabular}

LU (Landasan Ulin), BS( Banjarbaru Selatan), CK (Cempaka), MA (Mandastana), BA (Bakumpai), RB (Rantau Badauh), KI (karang Intan), MB (Martapura barat), AS (Astambul).

Tabel 5. Kelimpahan populasi lalat buah dari pemasangan perangkap pada setiap kabupaten di Kalimantan Selatan

\begin{tabular}{lcccccc}
\hline \multirow{2}{*}{ Spesies } & \multicolumn{2}{c}{ Banjarbaru } & \multicolumn{2}{c}{ Barito Kuala } & \multicolumn{2}{c}{ Banjar } \\
\cline { 2 - 7 } & Populasi & Persentase & Populasi & Persentase & Populasi & Persentase \\
\hline B. carambolae & 3890 & 25,2 & 377 & 36,3 & 3049 & 32,0 \\
B. papayae & 3116 & 20,2 & 224 & 21,6 & 2548 & 26,8 \\
B. umbrosa & 3435 & 22,2 & 211 & 20,3 & 2112 & 22,3 \\
B. albistrigata & 47 & 0,3 & 20 & 1,9 & 0 & 0,1 \\
B. latifrons & 2323 & 15,1 & 153 & 14,7 & 977 & 10,3 \\
B. cucurbitae & 0 & 0,0 & 1 & 0,1 & 2 & 0,0 \\
B. occipitalis & 2649 & 17,1 & 52 & 5,0 & 838 & 8,8 \\
\hline
\end{tabular}

Tabel 6). Hasil analisis UPGMA dengan program MEGA 4 untuk nilai koefisien perbedaan jarak ketidaksamaan yang didasarkan pada 20 karakter PCRRAPD (Tabel 6 dan 7) didapatkan dua kelompok.
Kelompok pertama terbagi menjadi dua sub kelompok yaitu $B$. umbrosa dan $B$. occipitalis dengan jarak koefisien 0,900 dan sub kelompok B. latifrons dengan jarak koefisien 0,700. Kelompok kedua terbagi menjadi 


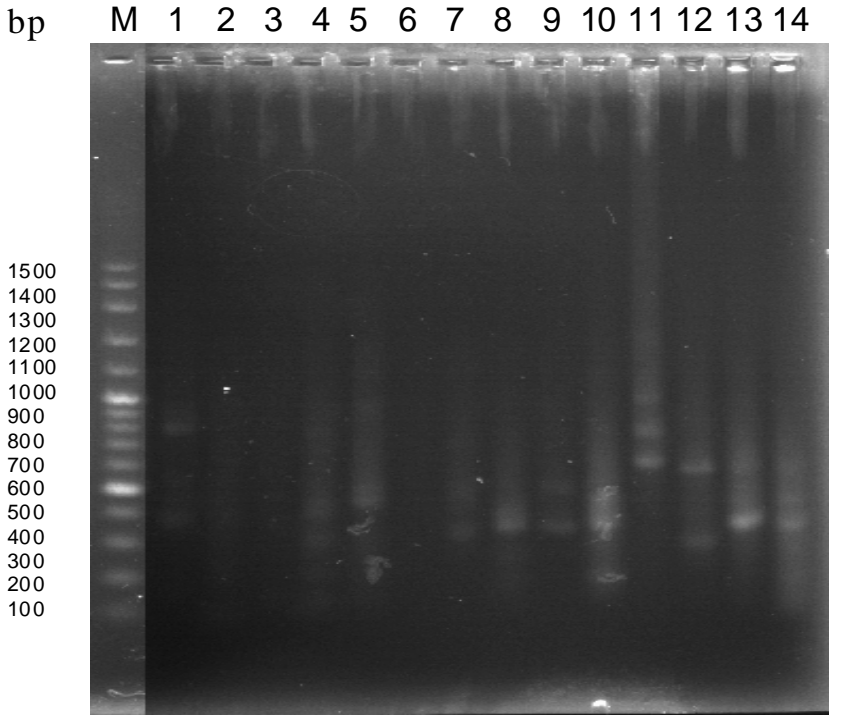

Gambar 2. Hasil amplifikasi DNA lalat buah dengan PCR mengunakan marker $100 \mathrm{bp}(\mathrm{M})$, nomor 1 sampai 14 adalah B. albistrigatal, B.carambolae1, B. latifrons 1, B. umbrosa7, B. albistrigata7, B. occipitalis7, B. papayae7, B. occipitalis16, B. umbrosa16, B. papayae16, B. albistrigata17, B. occipitalis 17, B. occipitalis8, B. latifrons8. Angka dibelakang spesies menunjukkan primer yang digunakan (OPL07, OPC01,OPL08,OPL16, OPL17).

2 sub kelompok yaitu sub kelompok B. papayae dan $B$. carambolae dengan jarak koefisien 0,850 , sub kelompok kedua B. cucurbitae dan B.albistrigata dengan jarak koefisien 0,900 dengan jarak koefisien keduanya 0,775. Jarak koefisien dari dua kelompok tersebut sebesar 0,670 (Gambar 3).

Hasil dari amplifikasi DNA total dari hasil PCR RAPD dengan primer yang digunakan dipilih hasil PCR yang terbaik dalam mengaplikasikan pita DNA dari semua spesies lalat buah yang sebelumnya sudah dipurifikasi telebih dahulu, kemudian dilakukan sekuensing mengunakan mesin sekuensing menunjukkan adanya homologi pada bagian sekuen DNA dari ketujuh spesies lalat buah tersebut yaitu pada 83 base pair/ bp (C), 101 bp (T), 265 bp (G), 420 bp (A), 432 bp (T), 600 bp (A). Panjang base pair berturut-turut untuk $B$. occipitalis, $B . \quad$ cucurbitae, $B . \quad$ albistrigata, $B$. carambolae, B. papayae, B. umbrosa adalah 615, 898, $570,969,898$ dan 615 dengan kecocokan pada genebank $100 \%$, B. latifrons 615 bp dengan kecocokan pada genebank 98\% (Tabel 8).

Hasil clustalw menunjukkan ada beberapa bagian sekuen yang memiliki homologi. B. papayae dan $B$. cucurbitae mempunyai tingkat kesamaan yang tinggi $86 \%$ (771 pasang basa yang sama). B. papayae dan $B$. occipitalis $65 \%$ (591). Lalat buah yang relatif mirip susunan nukleotida adalah $B$. carambolae dan $B$. papayae dari 1 sampai 85 sama pasangan basanya tetapi tingkat kesamaannya rendah 36\%. Sedangkan untuk B. latifrons, B. albistrigata, B. umbrosa sangat rendah tingkat kesamaannya dengan kata lain ketiga spesies ini berbeda keragamannya.

Hasil analisis UPGMA dengan program MEGA 4 untuk nilai koefisien perbedaan jarak ketidaksamaan yang didasarkan pada sekuen dari DNA tujuh spesies lalat buah didapatkan satu kelompok yang terdiri atas tiga sub kelompok. Sub kelompok pertama yaitu $B$. papayae, B. carambolae, B. occipitalis, B. latifrons. Sub kelompok kedua yaitu $B$. cucurbitae dan $B$. umbrosa. Sedangkan sub kelompok ketiga yaitu hanya B. albistrigata (Gambar 4).

Hasil amplifikasi DNA metode RAPD menunjukkan hasil polimorfisme pada pita-pita DNA (William et al., 1990). Adanya perubahan sekecil apapun dalam reaksi dapat mengubah jumlah dan intensitas produk amplifikasi sehingga keterulangan sulit untuk dipertahankan (Asokan et al., 2007; Anggereini, 2008). Hal yang harus diperhatikan pada proses PCR yaitu kesterilannya, karena PCR rentan terhadap kontaminasi. Walaupun terdapat kontaminasi yang sangat kecil, baik pada DNA maupun bahan-bahan PCR, maka hasilnya akan berbeda. Sedangkan kesulitan dalam memakai teknik RAPD yaitu: (1) tingkat reproduksibilitas pola penanda hasil percobaan dari laboratorium ke 
Tabel 6. Matrik data karakter molekuler RAPD tujuh spesies lalat buah hasil dari elektroforesis

\begin{tabular}{|c|c|c|c|c|c|c|c|c|c|c|c|c|c|c|c|c|c|c|c|c|}
\hline \multirow{2}{*}{ Spesies } & \multicolumn{20}{|c|}{ Karakter (bp) } \\
\hline & 50 & 100 & 150 & 200 & 250 & 300 & 350 & 400 & 450 & 500 & 550 & 600 & 650 & 700 & 750 & 800 & 850 & 900 & 950 & 1000 \\
\hline B. carambolae & 0 & 0 & 0 & 1 & 0 & 1 & 0 & 1 & 0 & 1 & 0 & 0 & 0 & 0 & 0 & 0 & 0 & 0 & 0 & 0 \\
\hline B. papayae & 0 & 1 & 1 & 1 & 0 & 1 & 1 & 1 & 0 & 1 & 1 & 1 & 0 & 0 & 0 & 0 & 0 & 0 & 0 & 0 \\
\hline B. umbrossa & 0 & 1 & 0 & 1 & 0 & 1 & 0 & 1 & 0 & 1 & 0 & 1 & 0 & 0 & 0 & 0 & 0 & 0 & 0 & 0 \\
\hline B. occipitalis & 0 & 0 & 0 & 1 & 1 & 1 & 1 & 0 & 0 & 1 & 0 & 1 & 0 & 1 & 0 & 0 & 0 & 0 & 0 & 1 \\
\hline B. albistrigata & 0 & 0 & 0 & 0 & 0 & 1 & 0 & 1 & 1 & 1 & 0 & 1 & 0 & 1 & 0 & 1 & 0 & 0 & 0 & 1 \\
\hline B. latifrons & 0 & 1 & 0 & 1 & 1 & 0 & 1 & 1 & 0 & 1 & 1 & 1 & 0 & 0 & 0 & 0 & 0 & 0 & 0 & 0 \\
\hline B. cucurbitae & 0 & 0 & 0 & 0 & 0 & 1 & 0 & 1 & 0 & 1 & 0 & 1 & 0 & 0 & 0 & 1 & 0 & 0 & 0 & 1 \\
\hline
\end{tabular}

Tabel 7. Matrik jarak genetik tujuh spesies lalat buah dari hasil RAPD berdasarkan analisis UPGMA

\begin{tabular}{lrrrrrrrrrrrrr}
\hline \multicolumn{1}{c}{ OUT } & B. a & B.ca & B.cu & B.la & B.oc & B.pa & B.um & & & \\
\hline B. albistrigata & 1 & & & & & & & & & & \\
B. carambolae & 0,750 & 1 & & & & & & & & & \\
B. cucurbitae & 0,900 & 0,850 & 1 & & & & & & & & \\
B. latifrons & 0,700 & 0,650 & 0,700 & 1 & & & & & & & \\
B. occipitalis & 0,700 & 0,550 & 0,700 & 0,700 & 1 & & & & & & & \\
B. papayae & 0,700 & 0,850 & 0,800 & 0,700 & 0,500 & 1 & & & & & & \\
B. umbrossa & 0,800 & 0,650 & 0,800 & 0,700 & 0,900 & 0,600 & 1 & & & & & \\
HTU1( 1 3) & 0,950 & 0,800 & 0,950 & 0,700 & 0,700 & 0,750 & 0,800 & 1 & & & & \\
HTU2( 5 7) & 0,750 & 0,600 & 0,750 & 0,700 & 0,950 & 0,550 & 0,950 & 0,750 & 1 & & & \\
HTU3( 2 6) & 0,725 & 0,925 & 0,825 & 0,675 & 0,525 & 0,925 & 0,625 & 0,775 & 0,575 & 1 & & \\
HTU4( 8 10) & 0,838 & 0,863 & 0,888 & 0,688 & 0,613 & 0,838 & 0,713 & 0,888 & 0,663 & 0,888 & 1 & \\
HTU5( 4 9) & 0,733 & 0,617 & 0,733 & 0,800 & 0,867 & 0,600 & 0,867 & 0,733 & 0,900 & 0,608 & 0,671 & 1 \\
HTU6( 11 12) & 0,785 & 0,740 & 0,810 & 0,744 & 0,740 & 0,719 & 0,790 & 0,810 & 0,781 & 0,748 & 0,835 & 0,835 & 1 \\
\hline
\end{tabular}

B.a (B. albistrigata de Meijere), B.ca (B. carambolae Drew \& Hancock),B.cu ( B. cucurbitae Coquillet), B.la (B. latifrons Hendel), B. oc (B. occipitalis

Bezzi), B. pa (B. papayae Drew dan Hancock), B. um (B. umbrosa Drew \& Hancock). 


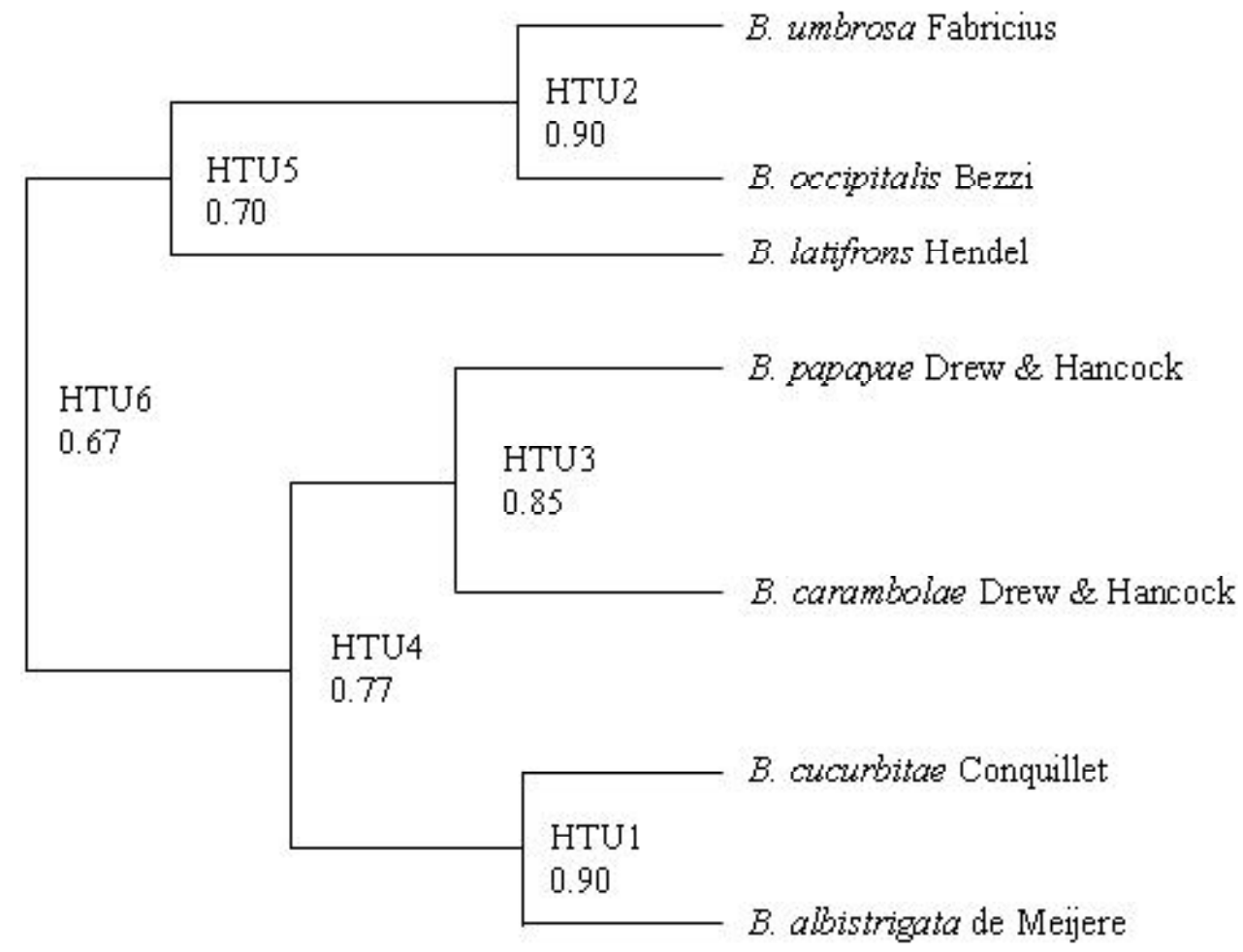

Gambar 3. Dendrogram tujuh spesies lalat buah hasil pemasangan perangkap dan pengumpulan buah berdasarkan karakter molekuler (PCR-RAPD).

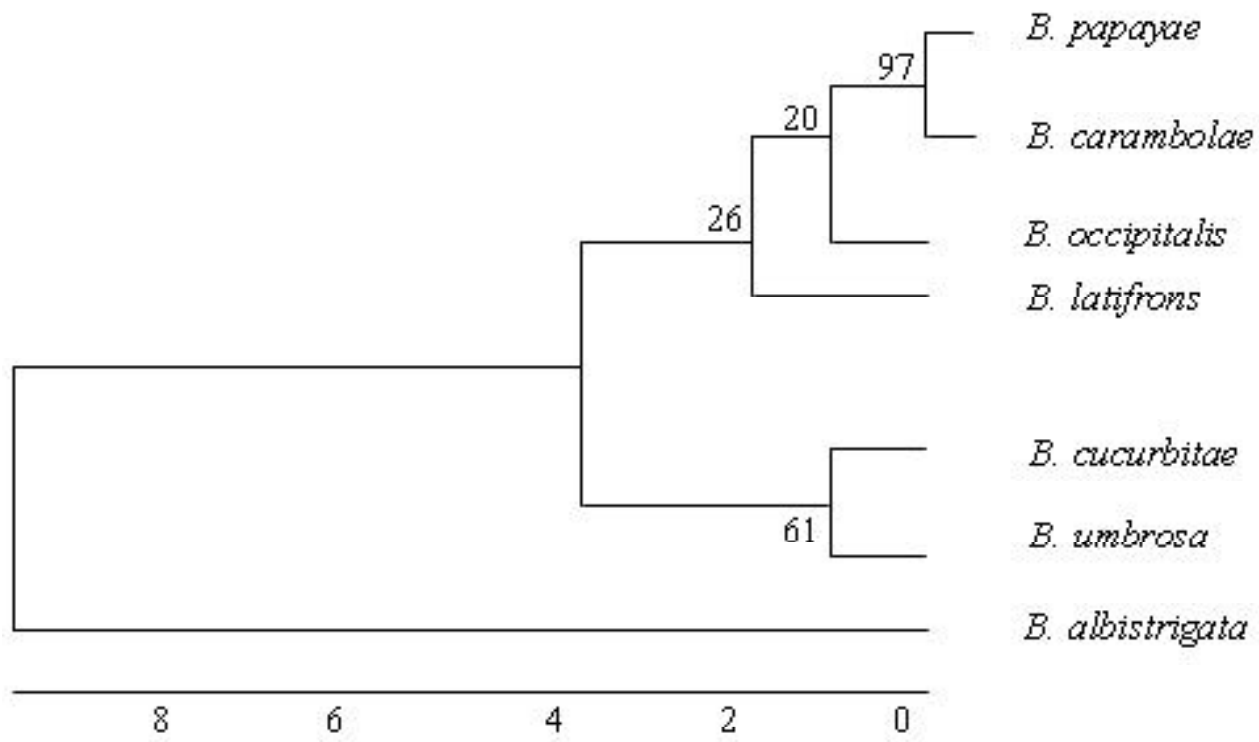

Gambar 4. Dendrogram tujuh spesies lalat buah hasil sekuensing DNA.

laboratorium berbeda bahkan dalam laboratorium yang sama, (2) sangat sensitif terhadap variasi konsentrasi DNA, dan (3) memerlukan konsentrasi primer dan kondisi siklus suhu yang optimal pada saat pengujian. Muladno (2010) menambahkan RAPD tidak dapat membedakan individu homozigot dan heterozigot karena bersifat sebagai penanda dominan serta sulit mendeteksi perubahan yang kecil pada struktur DNA. Sekuens DNA penyusun gen dari satu spesies seringkali mirip (homolog) dengan sekuens DNA penyusun gen yang sama dari spesies lain. Berbeda dengan sekuens DNA bukan gen, sehingga urutan sekuens DNA tertentu hanya terdapat pada spesies tertentu saja. 
Tabel 8. Perbandingan hasil sekuen DNA tujuh spesies lalat buah dari Kalimantan Selatan

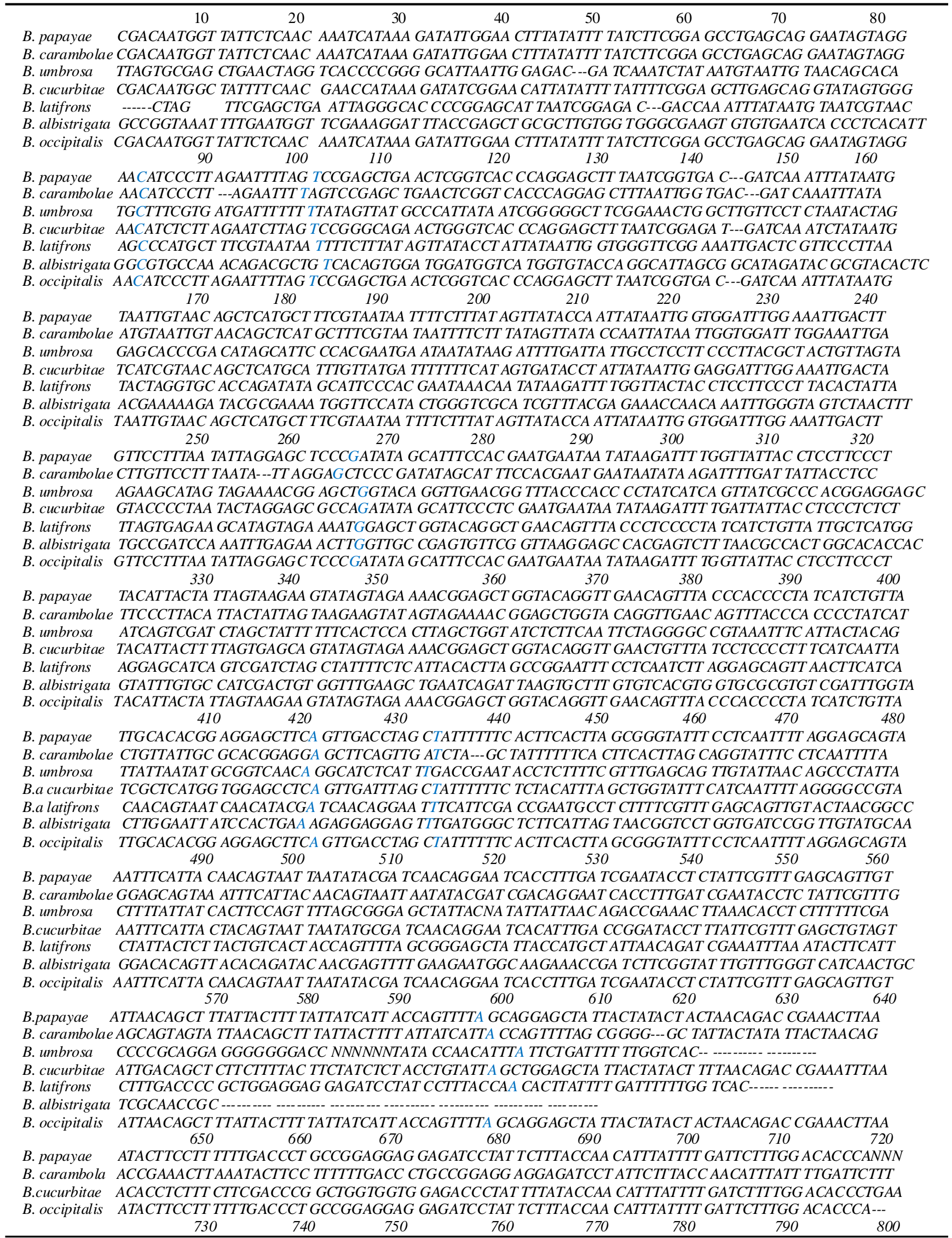


Sekuen DNA yang mempunyai hubungan kekerabatan dapat diidentifikasi dengan menempati cabang atau outgroup yang berdekatan yang membentuk pohon filogenetika. Perbedaan DNA lebih banyak dipakai karena dianggap lebih stabil dalam perkembangan spesies dibandingkan dengan perbedaan morfologi (William et al., 1990). Menurut Putra (2005) ada dua hal dasar yang digunakan untuk identifikasi yaitu menggunakan karakter tubuh seperti morfologi, anatomi, perilaku dan fisiologi. Selain itu, dapat dilakukan dengan memanfaatkan untai basa DNA yang terdapat pada selsel serangga sebagai pencirinya (Putra, 2005). Identifikasi DNA spesies dapat menjadi alat yang sangat berguna dalam entomologi meski tidak menggantikan identifikasi spesies secara konvensional. Identifikasi visual dapat digunakan untuk membedakan antara dua jenis karakteristik fisik dan perilaku sangat mirip atau identik. Sebuah identifikasi menyeluruh dari spesies melalui metode konvensional diperlukan sebelum mengunakan analisis DNA (Anggereini, 2008).

\section{SIMPULAN}

Identifikasi secara morfologi lalat buah hasil dari pemasangan perangkap dan penggumpulan buah terserang pada sembilan kecamatan di Kalimantan Selatan ditemukan tujuh spesies lalat buah yaitu $B$. carambolae, B. papayae, B.umbrosa, B. occipitalis, $B$. albistrigata, B. cucurbitae dan B. latifrons. Hasil analisis nilai koefisien perbedaan jarak ketidaksamaan yang didasarkan pada ciri morfologi dan metode RAPD menunjukkan perbedaan dalam pembagian kelompok dan sub kelompok. Hasil sekuensing DNA lebih mudah untuk membedakan B. carambolae dan B. papayae yang mempunyai hubungan kekerabatan sangat dekat. Perbedaan DNA lebih stabil dalam perkembangan spesies dibandingkan dengan perkembangan morfologis.

\section{DAFTAR PUSTAKA}

Anggereini E. 2008. Random amplified polymorphic DNA (RAPD), suatu metode analisis DNA dalam menjelaskan berbagai fenomena biologi. J. Biosp. 1(2):73-76.

Asokan R, Khrisna Kumar NK, \& Verghese A. 2007. Molecular identification of fruit flies Bactrocera spp. (Diptera: Tephritidae) using mitochondrial cytochrome oxidase I. Curr. Sci. 93(12): 16681669.
Asrida E \& Susilo FX. 2001. Respons berbagai jenis lalat buah belimbing terhadap pembungkusan buah. J. Pen S. Tek. 7(1): 76-86.

Bahagiawati \& Rijzaani H. 2005. Pengelompokan biotipe wereng cokelat berdasarkan hasil PCR-RAPD. J. Hayati 12(1):1-6.

Drew RAI. 1989. The tropical fruit flies (Diptera: Tephritidae: Dacinae) of the Australasian and Oceanian regions. J. Mem. Qd Mus. 26: 1.

Drew RAI \& Hancock DL. 1994. The Bactrocera dorsalis Complex of fruit flies (Diptera: Tephritidae : Dacinae) in Asia. Bulletin of Entomologycal Research: Suplement Series Number 2. In Suplement 2. Departement of Primary Industries. Australia. 11-13.

Fatchiyah \& Estri LA. 2011. Pelatihan analisis fingerprinting DNA tanaman dengan metode RAPD balai besar perbenihan dan proteksi tanaman perkebunan (BBP2TP) Surabaya. Laboratorium Sentral Ilmu Hayati (LSIH). Universitas Brawijaya. 4 - 6 Juli 2011.

Gawel NJ \& Bartlett AC. 1993. Characterization of differences between whiteflies using PCRRAPD. J. Insect Mol. Biol. 2(1):33-38.

Goodwin RH, Xue BG, Kuske CR, \& Sears MK. 1994. Amplication of plasmid DNA to detect plant pathogenic mycoplasma like organisms. J. Ann. Appl. Biol. 124:27-36.

Ginting R. 2009. Keanekaragaman lalat buah (Diptera : Tephritidae) di Jakarta, Depok dan Bogor sebagai bahan kajian penyusunan analisis risiko hama. Tesis. Sekolah Pascasarjana. Institut Pertanian Bogor.

Griffith University, Brisbane, Australia dan Ministry of Agriculture, Republic of Indonesia. 2008. Second training workshop on fruit flies of Indonesia: Their Identification and Pest Status. 10-14 March 2008.

Heckel DT. 1995. Randomly amplified polymorphic DNA differences between strains of diamondback moth (Lepidoptera: Plutellidae) susceptible or resistant to Bacillus thuringiensis. J. Ann. Entomol. Soc. Am. 88 (4): 20 - 34. 
Kalshoven LGE. 1981. Pest of crops in Indonesia. Revised and Translated by PA Van Der Laan. PT. Ichtiar Baru. Jakarta.

Kuswadi AN. 2001. Panduan Lalat Buah. Diunduh di http://www.deptan.go.id /ditlinhorti /makalah /lalat_buah.html pada tanggal 20 April 2012.

Muladno. 2010. Teknologi Rekayasa Genetika. IPB Press.

McPheron BA\& Steck GJ, 1996. Overview of research on the behavior of fruit flies. In Fruit Fly Pests: A World Assessment of Their Biology and Management. Florida: St Lucie Press.

Ortiz H, Frias D, \& Selivon D. 2006. Taxonomy of Immature Stages: New Morphological Character for Tephritidae Larvae Identification. Proceedings of the $7^{\text {th }}$ International Symposium on Fruit Flies Economic Importance 10-15 September 2006. Brasil. 2944.

Putra NS. 2005. Hama lalat buah dan pengendaliannya. Kanisus. Yogyakarta.

Sappanukhro P, Petcharat J, Nualsri J, \& Permkam S. 2011. Identification of Liriomyza spp. (Dipteral: Agromyzidae) on yardlog bean and cucumber in Songkhla province: II. Using random Ampliflied polymorphic DNA (RAPD) and male distiphallus technique. Faculty of Natural Resources. Prince of Songkla University. J. Agric. Tech. 7(2):349368.

Siwi SS. 2004. Jenis-jenis lalat buah penting di Indonesia dan macam tanaman inangnya. Balai Besar Penelitian dan Pengembangan Bioteknologi dan Sumber Daya Genetik Pertanian. Bogor.

Siwi SS, Purnama H, \& Suputa E. 2006. Taksonomi dan bioekologi lalat buah di Indonesia (Diptera:Tephritidae). Balai Besar Penelitian dan Pengembangan Bioteknologi dan Sumber Daya Genetik Pertanian. Departemen of Argriculture, Fisheries and Forestry Australia.
Smith PT, Srini K, \& Karen AA. 2003. Phylogenetic relationships among Bactrocera species (Diptera: Tephritidae) inferred from mitochondrial DNA sequences. J. Mol. Phylogenet. Evol. 26:8-17.

Sodiq M. 1993. Aspek biologi dan sebaran populasi lalat buah pada tanaman mangga dalam kaitan dengan pengembangan model pengendalian hama terpadu. Disertasi. Program Pascasarjana Universitas Airlangga.

Soesilohadi RCH. 2002. Dinamika populasi lalat buah, Bactrocera carambolae Drew dan Handcock (Diptera: Tephritidae). Disertasi. Program Pascasarjana, ITB.

Suputa E, Martono Z, Hussein AT, \& Arminudin. 2007. Preliminary study: Odontoponera denticulata as a potential predator to reduce true fruit fly population in Jogjakarta. J. Ilmu-Ilmu Pertanian 2007 edisi khusus 3:351-356

Swibawa IG, Susilo FX, Murti I, \& Ristiyani E. 2003. Serangan Dacus cucurbitae (Diptera: Trypetidae) pada buah mentimun dan pare yang dibungkus pada saat pentil. J. HPT Tropika 3(2): $43-46$.

Tamura K, Dudley J, Nei M, \& Kumar S. 2007. MEGA4: Molecular evolutionary genetics analysis (MEGA) software version 4.0. Mol. Biol Evol. 24:1596-1599.

William JGAR, Kublecik KJ, Liwak JA, Rafaski SV, \& Tinggey. 1990. DNA Polymorphism amplified by arbitrary primers are useful genetic markers. Nucleic Acid Res. 18:6531-6535.

White IM \& Hancock DL. 2007. Pest spesies of Dacini (Tephritidae). CABIKEY for WINDOWS. CAB International. International Institute of Entomology dalam CAB International. 2007. Crop Protection Compedium. Global Module. 2nd Edition. CDROM.

Zhang L \& Zhang ZY. 2007. Random amplified polymorphic DNA identification of six Bactrocera (Diptera: Tephritidae) species in Yunnan province of Southwest China. Chin. J. Appl. Ecol. 2007. 18(5):1163-1166. 